\title{
Studi Pemanfaatan Ruang Publik pada Komentar “Opini Anda” di RRI Pontianak
}

\author{
Redatin Parwadi
}

ABSTRACT

\begin{abstract}
This research aimed to investigate the use of public segment and audiences' mapping of program Kopi Anda or Your Opinion Comment at RRI Pontianak. The research result showed that community's response towards Your Opinion Comments segment at RRI Pontianak was highly positive. During a six-month research, the number of responses was reaching no less than 230 peoples, consisting of 200 males and 30 famales. There was 178 topics aired interactively and obtained 1.744 responses. On average, a topic was responded by 8 to 13 responses. The most favorite topic was politic (especially those which dealing with government administration). Mostly responses were addressed to executive officers and legislative members. Although the people were enthusiastically in participating to provide suggestion, inputs, and criticisms on the public policy, in terms of provincial or district/municipality, but responses requiring time, fund, and ideas from the people were rarely being cared. One possible reason for such problems derived for the fact that the officers and legislative members have never listened to the radio, despite the power of radio as communication media-therefore, as mediator-between people and their government as well as their representatives in regional legislative institution.
\end{abstract}

Kata kunci: ruang publik, tanggapan, media, partisipasi, pejabat publik

\section{Pendahuluan}

\subsection{Latar Belakang Penelitian}

Era reformasi memberikan dampak positif terhadap aspek kehidupan masyarakat, terutama berkembangnya kebebasan dalam mengemukakan pendapat. Majelis Permusyawaratan Rakyat (MPR) Republik Indonesia telah melakukan amandemen UUD 1945, sebanyak 4 (empat) kali. Pasal 28 tetap dipertahankan dan dalam amandemen yang kedua kali, terdapat penambahan Bab XA tentang Hak Asasi Manusia (HAM), yang berisi 10 (sepuluh) pasal yaitu pasal, 28 A sampai dengan pasal $28 \mathrm{~J}$. Khusus kaitan hak publik untuk melakukan komunikasi dan mendapatkan informasi, pasal 28 F mengatur bahwa setiap orang berhak untuk berkomukasi dan memperoleh informasi untuk mengembangkan pribadi dan lingkungan sosialnya, serta berhak untuk mencari, memperolah, memiliki, menyimpan, mengolah, dan menyampaikan informasi dengan menggunakan segala jenis saluran yang tersedia.

Di era reformasi rakyat mulai menemukan hak dan kewajibannya untuk bersuara, mendapatkan dan menyebarkan informasi demi kepentingan bersama. Kegiatan mengkritisi kebijakan penyelenggara negara (pemerintah, parlemen, dan lembaga peradilan) dapat dilakukan secara terbuka, terutama melalui mass media, baik media cetak maupun media elektronik. Tidak terlalu sulit masyarakat menyampaikan uneg-uneg/kritik, melalui ruang publik di surat kabar, majalah, 
televisi, radio, serta dalam forum diskusi/seminar. Laporan penelitian ini merupakan hasil kajian terhadap pemanfaatan ruang publik yang disediakankan RRI Pontianak dalam acara dialog interaktif "Kopi Anda". Selama melakukan observasi enam bulan, ternyata ruang publik yang disediakan oleh RRI Pontianak mendapatkan sambutan yang baik dari masyarakat. Masalah dalam penelitian ini adalah bagaimana masyarakat/pendengar memanfaatkan ruang publik yang tersedia pada acara Kopi Anda, untuk menyampaikan tanggapan atas suatu topik dia$\log$. Masalah ini sungguh penting untuk diteliti, karena acara ini menyediakan ruang publik, yang dapat dimanfaatkan sebebas-bebasnya oleh pendengar/penanggap dalam menyampaikan pendapat, sebagai wujud keberanian masyarakat.

Penelitian ini bertujuan untuk mendeskripsikan pemanfaatan ruang publik, dan memetakan tanggapan publik atas topik yang menjadi materi dialog berdasarkan bidang, bernilai atau tidak, publik yang ditujukan, dan lain-lain. Selanjutnya, kegunaan hasil penelitian adalah sebagai masukan bagi RRI, dan instansi yang terkait atas feedback yang masuk melalui dialog interaktif, serta bagi masyarakat dapat memotivasi untuk menyampaikan tanggapannya melalui ruang publik yang tersedia.

\subsection{Ruang Lingkup Penelitian}

Salah satu program RRI Pontianak adalah progama tiga (Pro 3). Pro 3 mempunyai lima acara unggulan yaitu Kopi Anda (Komentar Opini Anda), Mamaku (Masalahmu dan Masalahku), Pastela (Pasti Anda Suka Tembang Lama), Kalimantan Barat Hari Ini, serta Dinamika Khatulistiwa.

Dalam penelitian ini, yang menjadi fokus penelitian adalah programa 3 (Pro 3) khususnya pada acara Kopi Anda (Komentar Opini Anda) yang disiarkan setiap hari pada pukul 06.30 sampai 07.00 WIB. Alasan pemilihan Kopi Anda sebagai kajian adalah sebagai dialog interaktif yang bebas, tidak ada narasumber kecuali penyiar sebagai moderator. Pendengar dapat langsung menyampaikan tanggapan sehingga pendengar dapat memanfaatkan kebebasannya secara terbuka, dan bertanggung jawab.

\subsection{Tinjauan Pustaka}

RRI sebagai lembaga penyiaran publik atau radio publik terikat pada peraturan perundangundangan yaitu Undang Undang Nomor 32 Tahun 2002 tentang Penyiaran dan persyaratan dari Unesco. Menurut UU No. 32 Tahun 2002. Pasal 14 Ayat 1, yang disebut Lembaga Penyiaan Publik adalah lembaga penyiaran yang berbentuk badan hukum yang didirikan oleh negara, bersifat independen, netral, tidak komersial, dan berfungsi memberikan layanan untuk kepentingan masyarakat. Menurut Ayat 2 pasat tersebut, Lembaga Penyiaran Publik terdiri atas Radio Republik Indonesia (RRI) dan Televisi Republik Indonesia (TVRI) yang stasiun pusat penyiarannya berada di ibukota negara Republik Indonesia.

Menurut Unesco (dalam Saleh, 2005), Lembaga Penyiaran Publik seperti Radio harus memenuhi peryaratan atau prinsip-pinsip sebagai berikut: (1) universality, artinya harus dapat diakses oleh setiap warga negara diseluruh wilayah suatu negara; (2) diversity, yaitu ada tiga hal yang harus dijalankan oleh lembaga penyiaan publik: penyajian acara, memenuhi kebergaman khalayak, dan dalam keberagaman topik; (3) independence, lembaga penyiaran publik merupakan forum atau ruang publik, tempat bagi pengaturan ide serta penyampaian kritik secara bebas; dan (4) Distinctiveness, artinya harus dapat menampilkan acara yang berbeda dengan Lembaga Penyiaran Komersial, sehingga mempunyai ciri khusus/khas sebagai lembaga penyiaran publik.

Berdasar rambu-rambu ciri-ciri tersebut, menurut Saleh (2005), RRI harus menunjukkan kepada masyarakat hal-hal sebagai berikut: (1) selalu komitmen dengan menyiarkan acara yang benar-benar dirasakan kemanfaatannya oleh masyarakat, baik berupa informasi, pendidikan, dan hiburan, menyediakan ruang publik (public sphare) bagi masyarakat, untuk dilaksanakannya dialog interaktif antara pihak pemerintah, masyarakat dan pihak lain yang terkait; (2) mampu 
mengupayakan adanya acara siaran yang berorientasi pada kebutuhan masyarakat setempat (local content).

Perwujudan dari kuwajiban RRI kepada masyarakat adalah memberikan kesempatan masyarakat untuk ikut berpartisipasi dalam pengawasan dan penilaian serta aktif ikut dalam acara dalam ruang publik yang disediakan oleh RRI. Ruang publik adalah arena komunikasi dan pengembangan pemikiran antara masyarakat dan penguasa, penguasa dengan masyarakat, masyarakat dengan masyarakat dan antargolongan masyarakat. RRI sebagai radio publik harus dapat mempertanggungjawabkan kepada publik, artinya apa yang disiarkan RRI harus bermanfaat bagi masyarakat, memberikan pencerahan/pendidikan dan hiburan. Berhasil tidaknya RRI sebagai radio publik, salah satu tolok ukkurnya adalah pemanfaatan ruang publik secara efektif.

Secara teoretis, RRI adalah salah satu media komunikasi massa. Komunikasi massa adalah komunikasi sosial yang dilakukan oleh komunikator dengan khalayaknya melalui media tertentu. Jika dilihat dari komunikatornya, maka komunikasi massa adalah komunikasi yang terorganisasikan dengan baik. (Laswell, 1984), lihat juga (Rakhmat, 2001), mengemukakan ada tiga macam aktivitas pokok komunikasi, yaitu: sebagai media pengawasan lingkungan; sarana koneksi antarbagian masyarakat dalam menanggapi lingkungan; dan transmisi warisan sosial dari suatu generasi ke generasi berikutnya.

Dalam teori masyarakat massa, yang dikemukakan dalam karya-karya Mills (1956), Kornhauser (1968), Bramson (1961), Bill (1961), Ginser (1979) dan Mc Quail (1989), tedapat ketergantungan timbal balik antarinstitusi pemegang kekuasaan dan integrasi media terhadap sumber kekuasaan sosial dan otoritas. Oleh karena itu, isi pesan media cenderung melayani kepentingan pemegang kekuasaan politik dan ekonomi. Teori ini memberikan gambaran yang jelas mengenai keberadaan dan kadar kekuasaan media dalam masyarakat. Kenyataan ini, menurut Mc Quail (1989), menunjukkan bahwa media dapat dikendalikan atau dikelola secara monopolistik untuk dijadikan alat utama yang efektif dalam mengorganisasi massa. Jika penguasa ingin memengaruhi massa, maka ia harus bisa menguasai dan mengendalikan media massa. Oleh karena itu, dilihat dari sejarahnya, radio selalu dekat dalam pengaruh penguasa.

Radio mempunyai kekuatan atau daya tembus yang kuat dalam jumlah khalayak yang besar, jangkauan jarak yang jauh dan serempak serta modal/investasi yang relatif kecil. Radio dan televisi termasuk media massa yang populer, isi pesannya mempunyai pengaruh kuat terhadap khalayaknya (powerfull effect). Hal ini seperti dikemukakan oleh Wilbur Schramm (1971), dalam pembahasan teori dampak media diacu sebagai teori peluru. Model ini mengandaikan dampak langsung sejalan dengan perhatian pengirim pesan/berita atau tercakup dalam pesan (pesan yang disampaikan oleh sender akan diterima sama tanpa cacat oleh receiver).

Menurut Effendy (1984), seorang komunikator media massa harus memahami ciri-ciri komunikasi massa sebagai berikut: komunikasi massa berlangsung satu arah; komunikator pada komunikasi massa melembaga; komunikasi bersifat umum; pesan media massa mengandung keserampakan; dan komunikasi massa bersifat heterogen. Selain ciri-ciri tersebut, audiens suatu media massa jumlahnya besar; heterogen, anonim dan tidak terlembagakan; terikat pada suatu perhatian yang sama, yaitu pesan dari media yang sama; tidak berada pada suatu tempat yang sama, yaitu pesan dari media yang sama, terpisah-pisah secara fisik; dan tidak dapat memberikan arus balik (feedback) secara langsung pada saat itu.

Berdasarkan ciri-ciri yang telah dipaparkan tersebut, RRI sebagai media komunikasi massa memenuhi sebagai media yang tergolong teratur, terencana, melembaga sebagai bagian dari lembaga birokrasi yang mendapatkan pembiayaan dari negara/masyarakat melalui anggaran negara, sebagai bagian dari penyelenggara visi dan missi birokrasi pemerintahan, memberikan informasi kepada siapa pun, dengan lokasi yang terpencar dan terpisah, serta memenuhi fungsinya sebagai penyebar informasi untuk memenuhi hak 
masyarakat akan kebutuhan informasi.

Jika disimak tentang salah satu ciri media massa yaitu tidak dapat memberikan arus balik (feedback) secara langsung pada saat itu (saat terjadinya komunikasi), tidak sepenuhnya benar. Hal ini disebabkan adanya beberapa mata acara siaran radio yang dilakukan secara interaktif antara komunikator dan khalayak, pada waktu itu pula khalayak dapat memberikan feedback. Acara Kopi Anda, dan Dinamika Khatulistiwa misalnya merupakan media komunikasi dengan feedback langsung.

RRI melalui acara dialog interaktif dapat langsung menarik feedback dari pendengarnya. Hal ini sesuai dengan model komunikasi menurut J. Seiler (1988), yang menyatakan bahwa dalam proses komunikasi, terdapat beberapa unsur penting yaitu: (1) source (pengirim berita/pesan; (2) receiver (penerima pesan);(3) message (pesan); (4) channel (saluran); noise (gangguan);(5) environment (lingkungan); dan (6) feed-back (umpan balik/balikan). Khusus mengenai feed-back atau balikan atau umpan balik adalah tanggapan dan reaksi dari receiver atau penerima pesan yang dilakukan secara langsung dan tidak langsung, terhadap apa yang dipesankan/dikirimkan oleh source atau pengirim pesan.

Menganalisis feed-back yang berasal dari pendengar radio, berdasarkan pendapat Mc Quail dan Windhal (1993), audience tidak lagi dipandang pasif sebagai objek komunikasi, namun berlaku aktif. Jadi, audience diberikan kebebasan pilihan informasi sesuai dengan kebutuhannya. Keaktifan publik RRI dapat dilihat dalam pemanfaatan ruang publik yang disediakan, dengan cara memberikan tanggapan terhadap topik dialog dalam acara Kopi Anda.

\subsection{Metode Penelitian}

Objek penelitian ini adalah tanggapan masyarakat terhadap topik dialog interaktif Kopi Anda dalam ruang publik yang disediakan dalam Pro 3. Sampel diambil selama kurun waktu enam bulan (Maret, April, Mei, Juni, September dan November 2005). Analisis isi topik pada bulan tersebut dilakukan secara sengaja (metode purposive sampling) dengan pertimbangan bahwa data pada bulan Maret, April, Mei, Juni, dan September telah direkam/ disediakan oleh RRI, dan data bulan November yang direkam sendiri oleh peneliti. Selain itu, pertimbangan lain adalah orang yang memberikan tanggapannya pada bulan-bulan tersebut lebih bervariasi, khususnya perempuan yang memberikan tanggapannya lebih banyak ketimbang bulan lainnya.

Jenis penelitiannya adalah kualitatif deskriptif. Selain itu, juga menggunakan analisis isi tanggapan. Teknik dan alat pengumpulan data, menggunakan wawancara, dokumentasi, dan observasi. Wawancara dilakukan terhadap pengambil kebijakan publik, yaitu pada beberapa pejabat di lingkungan Pemerintah Kota Pontianak dan Pemerintah Provinsi, serta anggota DPRD Kota Pontianak dan DPRD Provinsi Kalimantan Barat. Wawancara juga dilakukan terhadap pendengar yang sekaligus sebagai penanggap, serta para pejabat dan staf operasional dilingkungan RRI Pontianak.

\section{Hasil Penelitian dan Pembahasan}

\subsection{Penyediaan Ruang Publik}

RRI Pontianak sebagai Lembaga Penyiaran Publik menyediakan ruang publik pada beberapa program siarannya, yaitu melalui Pro 3 dengan acara unggulan Kopi Anda (Komentar Opini Anda), Mamaku (Masalahmu dan Masalahku), dan Dinamika Khatulistiwa. Selain Ruang publik yang berisi local content juga disediakan ruang publik lain berupa acara relai ke RRI Pusat yang terdiri atas Siaran Berita, Indonesia Menyapa, dan Varia Nusantara. Masing-masing acara siaran tersebut menggunakan waktu berbeda-beda. Untuk melihat bagaimana distribusi waktu untuk ruang publik yang disediakan Pro. 3, berdasarkan jenis siarannya, dapat dilihat pada Tabel 1.

Berdasarkan Tabel 1, ruang publik yang disediakan oleh RRI Pontianak melalui Pro 3 cukup besar yaitu 41,67\% dari jumlah siaran setiap hari selama 17 jam. Selebihnya adalah untuk acara hiburan, pendidikan, iklan, dan lain-lain. Hal ini 
Tabel 1

Ruang Publik Berdasar Jenis Siaran dan Waktu yang Digunakan

\begin{tabular}{|l|c|c|}
\hline \multicolumn{1}{|c|}{ Jenis Siaran } & Jumlah Waktu (Menit) & Prosentase (\%) \\
\hline Kopi Anda & 30 & 2,94 \\
\hline Masalahmu Masalahku & 45 & 4,41 \\
\hline Dinamika Khatulistiwa & 60 & 5,88 \\
\hline Informasi Sela & 5 & 0,49 \\
\hline Relai pada RRI Pusat: & 180 & 17,65 \\
$-\quad$ Siaran Berita & 60 & 5,88 \\
- Indonesia Menyapa & 45 & 4,41 \\
$\quad$ Varia Nusantara & & \\
\hline Jumlah & 425 & 41,67 \\
\hline
\end{tabular}

Sumber: Data Primer, 2005

menunjukkan bahwa RRI Pontianak sebagai lembaga penyiaran publik sudah memadai. Tetapi jika ruang publik diartikan khusus acara yang ada dialog interaktifnya, di mana masyarakat ikut aktif berpartisipasi dalam dialog tersebut, maka baru sekitar 18,66\% saja ruang publik yang disediakan oleh RRI melalui Pro 3 (Kopi Anda, Dinamika Khatulistiwa, Mamaku, serta Indonesia Menyapa)

Sebagaimana yang telah dijelaskan terdahulu, penelitian hanya memfokuskan atau menganalisis ruang publik pada acara dialog interakif Kopi Anda. Acara tersebut disiarkan pada setiap pagi pukul 06.30 sampai dengan pukul 07.00. Mekanismenya sebagai berikut: dialog dimoderatori oleh seorang penyiar. Topik dipilih dari salah satu judul yang ada di rubrik "Metropolis" harian Pontianak Post yang terbit hari itu. Pendengar, yang sekaligus menjadi penanggap, dengan menggunakan pesawat telepon atau telepon gengam dapat menghubungi pesawat telepon yang ada di stu-

Tabel 2.

Distribusi Penanggap Berdasarkan Frekuensi Tanggapannya (Selama 6 Bulan)

\begin{tabular}{|c|c|c|}
\hline Frekuenai Tanggapan & Jumlah Orang Penanggap & Prosentase (\%) \\
\hline $1-5$ & 193 & 83,92 \\
\hline $6-15$ & 13 & 5,66 \\
\hline $16-25$ & 9 & 3,91 \\
\hline $26-35$ & 10 & 4,35 \\
\hline $36-45$ & 3 & 1,30 \\
\hline $46-55$ & 2 & 0,86 \\
\hline Jumlah & 230 & 100,00 \\
\hline
\end{tabular}

Sumber: Data Primer, 2005 
Tabel 3.

Jumlah Waktu yang Digunakan untuk Memberikan Tanggapan

\begin{tabular}{|c|c|c|}
\hline Lama Waktu (Detik) & Jumlah Tanggapan/Orang & Prosentase \% \\
\hline $21-35$ & 19 & 6,09 \\
\hline $36-50$ & 46 & 14,74 \\
\hline $51-65$ & 86 & 27,56 \\
\hline $66-80$ & 92 & 29,49 \\
\hline $86-95$ & 42 & 13,46 \\
\hline $96-110$ & 17 & 5,45 \\
\hline $111-125$ & 10 & 3,21 \\
\hline Jumlah & 312 & 100,00 \\
\hline
\end{tabular}

Sumber: Data Primer, 2005

dio, di mana penyiar berada.

Berdasarkan data hasil penelitian selama enam bulan, waktu dialog adalah 30 menit, jumlah pendengar sekaligus penanggap selama enam bulan penelitian adalah 230 orang, yang terdiri atas 30 orang perempuan dan 200 laki-laki. Frekuensi tanggapan yang disampaikan oleh penanggap terhadap topik yang diinteraktifkan berbeda-beda. Ada penanggap yang sering menyampaikan tanggapan pada acara Kopi Anda, artinya hampir setiap hari mereka memberikan komentar atau tanggapan terhadap topik yang dibahas. Ada pula yang hanya sesekali saja memberikan tanggapan terhadap acara tersebut. Untuk mengetahui frekuensi masing-masing penanggap terhadap setiap topik yang di interaktipkan selama enam bulan dapat dilihat pada Tabel 2.

Tabel 2 menunjukkan bahwa sebagian besar penanggap atau $83,92 \%$ hanya sekali sampai lima kali memberikan tanggapannya dalam kurun waktu enam bulan, dan hanya sebagian kecil atau $0,86 \%$ penanggap yang frekuensi tanggapannya tergolong sangat sering (46-55) kali. Ini menunjukkan bahwa anggapan yang mengatakan acara Kopi Anda hanya ditanggapai oleh orang yang selalu sama tidak benar.

Sebagaimana telah disebutkan acara Kopi Anda hanya memakai durasi waktu 30 menit. Oleh karena itu, penaggap yang hendak menyampaikan tanggapannya harus berebut dengan penagggap lainnya. Bagi yang telah biasa memberikan tanggapan, umumnya lebih mudah connect dengan penyiar, sehingga mereka tampak lebih sering. Selain lebih mudah connect juga waktu yang digunakan untuk memberikan tanggapan, umumnya lebih lama, malah kadang-kadang tanggapannya menyimpang dari topik yang dibahas. Akibatnya, jumlah orang yang memberikan tanggapannya sangat terbatas. Untuk mengetahui seberapa besar jumlah waktu yang digunakan oleh seorang penanggap dalam menyampaikan tanggapannya terhadap satu topik dialog, dapat dilihat pada tabel berikut ini.

Tabel di atas menunjukkan bahwa umumnya $(57,05 \%)$ orang atau penanggap, menggunakan waktu sekitar 51 detik sampai 80 detik dalam sekali memberikan tanggapan. Hanya sebagian kecil $(3,21 \%)$ penanggap menggunakan waktu cukup lama (111-125 detik) dalam setiap memberikan tanggapannya. Adapun waktu paling singkat (21 - 35 detik) digunakan oleh $(6,09 \%)$ penanggap dalam setiap memberikan tanggapannya. Mereka umumnya memberikan tanggapan dengan tegas dan jelas terhadap topik yang dibahas.

\subsection{Pemilihan Topik}

Sumber atau "bank" topik yang dibahas adalah harian Pontianak Post, dalam rubrik "Metropolis". Sebagaimana telah dikemukakan, terdahulu topik diambil dari harian Pontianak Post yang 
Tabel 4

Distribusi Topik Berdasarkan Penggolongan Bidang

\begin{tabular}{|l|c|c|}
\hline \multicolumn{1}{|c|}{ Kelompok/Jenis } & Jumlah & Prosentase (\%) \\
\hline Politik & 69 & $39 \%$ \\
\hline Ekonomi/Keuangan & 59 & $33 \%$ \\
\hline Sosial/Budaya & 26 & $15 \%$ \\
\hline Hukum dan Korupsi & 18 & $10 \%$ \\
\hline Hankam & 6 & $3 \%$ \\
\hline Jumlah & 178 & $100 \%$ \\
\hline
\end{tabular}

Sumber: Data Primer, 2005

didasarkan atas kerjasama sindikasi antara keduanya, dengan memanfaatkan fungsi dan potensi masing-masing, dengan bentuk saling mengiklankan. Adapun pemilihan dan penentuan topik mana yang akan dibahas atau diinteraktifkan tergantung dari penyiar yang melaksanakan tugas pada saat itu. Jika menurut pengetahuan dan pemahaman penyiar bahwa topik yang dipilihnya itu merupakan topik yang hangat dan menarik pemerhati, maka topik itulah yang diinteraktifkan. Tak ada satu pun yang intervensi baik dari seseorang atau lembaga dalam pemilihan topik.

\subsection{Topik Berdasarkan Bidang}

Untuk memudahkan analisis ruang publik dan tanggapan dari pendengar yang menyampaikan tanggapan, topik dialog interaktif dibagi ke dalam: (1) bidang politik yang berisi tugas dan fungsi penyelenggara negara (eksekutif, legislatif dan yudikatif); (2) bidang ekonomi/keuangan yang berkaitan dengan penggunaan sumber daya; (3) sosial budaya; (4) hukum dan korupsi; dan (5) bidang pertahanan keamanan.

Penggolongan bidang topik, untuk mengetahui masyarakat atau pemerhati Pro 3 RRI Pontianak itu, lebih menyukai bidang-bidang yang mana? Ini berguna bagi para penyiar untuk membantu menentukan topik yang dibahas. Untuk mengetahui distribusi topik yang diinteraktifkan berdasarkan bidangnya, dapat dilihat pada Tabel 4.

Tabel 4 menunjukkan bahwa sebagian besar
(72\%) topik yang dibicarakan adalah berkaitan dengan politik (fungsi penyelenggara negara yaitu eksekutif, legislatif dan yudikatif) dan topik bidang ekonomi. Hanya sebagian kecil (3\%) topik yang diinteraktifkan, berkaitan dengan hankam. Hal ini menunjukkan bahwa menurut persepsi penyiar, pendengar atau penaggap lebih tertarik pada masalah-masalah politik, dibanding topik lain. Persepsi penyiar ini didukung dengan data jumlah penanggap pada topik yang termsuk masalah politik misalnya Ricuh di DPR, Bubarkan KPU karena Banyak Masalah, Kinerja Pemerintah Kota dan LPJ Eksekutif Diterima atau Ditolak, masingmasing mendapat tanggapan berkisar 19 sampai 22 orang penanggap.

\subsection{Tanggapan Berdasarkan Manfaat}

Tanggapan yang masuk dikategorikan berdasar manfaat, artinya apakah tanggapan ada relevansinya dengan topik atau tidak. Sebelum memaparkan jenis tanggapan berdasarkan manfaatnya, terlebih dahulu dijelaskan distribusi tanggapan terhadap topik yang disajikan pada Tabel 5.

Dari Tabel 5, terlihat bahwa sebagian besar (58\%) topik mendapatkan tanggapan antara 8-13 penanggap. Hanya sebagian kecil $(2,81 \%)$ topik yang ditanggapi oleh 2-4 penanggap. Ini menunjukkan, acara Kopi Anda dengan durasi 30 menit tersebut memang acara yang menarik dan mendapat perhatian para pemerhatinya. Data ini juga didukung ketika peneliti mewawancarai 
Tabel 5.

Jumlah Tanggapan terhadap Topik

\begin{tabular}{|c|c|c|}
\hline Tanggapan & Jumlah Topik & Prosentase \\
\hline $17-22$ & 5 & 3 \\
\hline $14-16$ & 9 & 5 \\
\hline $11-13$ & 16 & 9 \\
\hline $8-10$ & 87 & 49 \\
\hline $5-7$ & 56 & 31 \\
\hline $2-4$ & 5 & 3 \\
\hline Jumlah & 178 & 100 \\
\hline
\end{tabular}

Sumber: Data Primer, 2005

beberapa pendengar yang menyatakan kesulitan untuk ikut connect karena harus berebut dengan penanggap yang lain.

Tanggapan dari pendengar acara Kopi Anda, dapat diklasifikasikan kedalam dua golongan feedback yaitu tanggapan yang bernilai dan tanggapan yang kurang bernilai. Tanggapan yang bernilai mempunyai karakteristik adanya relevansi dengan topik yang dibahas dengan pendekatan problem solving berupa saran tindak lanjut. Tanggapan model ini biasanya berisi ketegasan setuju atau tidak setuju dengan alasan yang jelas, dan disertai dengan saran yang jelas pula, yang dapat dilaksanakan di lapangan. Adapun tanggapan yang kurang bernilai, adalah tanggapan yang kurang atau tidak terkait dengan topik dialog. Jenis tanggapan ini jauh menyimpang. Untuk mengetahui distribusi tanggapan berdasarkan manfaatnya (bernilai/tidak bernilai), dapat dilihat pada Tabel 6.

Tabel 6 menunjukkan bahwa semua topik yang diinteraktifkan selalu mendapatkan tanggapan dari para pemerhatinya. Berdasarkan data tersebut, sebagian besar (72,02\%) tanggapan yang dikemukakan oleh pemerhati ada relevansinya dengan topik yang diinteraktifkan. Hanya sebagian kecil (27,98\%) saja tanggapan yang dikemukakan tidak/kurang berkaitan dengan topik yang diinteraktifkan. Tanggapan yang bernilai akan sangat berguna bagi instansi atau lembaga yang terkait dengan topik dialog, baik sebagai masukan maupun untuk membantu pemecahan masalah yang dihadapi.

Di dalam pembahasan selanjutnya, tentang

Tabel 6

Distribusi Tanggapan Berdasar Manfaat

\begin{tabular}{|c|c|c|}
\hline Jenis & Jumlah & Prosentase (\%) \\
\hline Bernilai (terkait dengan topik) & 1.256 & $72,02 \%$ \\
\hline Tidak bernilai (tidak terkait dengan topik) & 488 & $27,98 \%$ \\
\hline Jumlah & 1.744 & $100,00 \%$ \\
\hline
\end{tabular}

Sumber: Data Primer, 2005 
kepedulian publik terhadap tanggapan, maka tanggapan yang tidak terkait dengan topik (tidak bernilai) akan dikeluarkan (tidak dibahas).

\subsection{Tanggapan Bernilai dan Publik yang Dituju}

Setelah diketahui berbagai jenis penggolongan topik dialog dan tanggapan, berikut ini diuraikan secara khusus tanggapan yang bernilai (ada kaitannya dengan topik) saja, dihubungkan dengan publik yang dituju. Dalam uraian ini, tanggapan yang tidak bernilai dikeluarkan atau tidak termasuk dalam pembahasan, karena tidak ada kaitannya dengan topik dan kurang bermafaat. Berikut ini disajikan distribusi tanggapan bernilai dalam kaitannya dengan publik yang dituju dalam Kopi Anda (Tabel 7).

Data tersebut menunjukkan bahwa tanggapan lebih banyak ditujukan pada pihak eksekutif sebesar 566 tanggapan atau 45,06\%, dan tanggapan untuk legislatifberjumlah 450 atau $36 \%$. Adapun lembaga Yudikatif dan lembaga usaha hanya $9,71 \%$. Hal ini menunjukkan bahwa masalah yang dikemas dalam topik diskusi lebih banyak terkait dengan fungsi lembaga eksekutif dan legislatif. Contoh topik-topik tersebut adalah mengenai Kenaikan BBM, Penertiban Pedagang Kaki Lima, Perda Penertiban Miras, Pembayaran Kompensasi BBM, dan lain-lain, penyelesainnya menyangkut tugas lembaga tersebut.

\subsection{Follow-up Tanggapan Hasil Dialog Interaktif Kopi Anda}

Hasil yang penting dalam dialog interaktif bukanlah sekedar mendapatkan tanggapan dari pendengar/penanggap, tetapi proses kelanjutan dari tanggapan yang diperoleh, apakah tanggapan itu ditindak lanjuti oleh instansi-instansi yang dituju atau tidak.

Sebagaimana telah dikemukakan terdahulu bahwa tanggapan terhadap topik dialog, sebagian besar ditujukan kepada eksekutif sebesar 566 atau $45 \%$. Namun, kenyataannya, tanggapan dari masyarakat tersebut tidak dipedulikan oleh pihakpihak yang terkait. Hal ini dapat dilihat dari data hasil penelitian yang menunjukkan bahwa pada instansi yang berhubungan dengan pengelolaan komunikasi dan informasi sangat sedikit unit yang mempunyai fungsi pengelola informasi yang berasal dari luar. Pada umumnya, instansi (beberapa yang peneliti kunjungi) tidak mengakses informasi yang berasal dari RRI, terutama hasil tanggapan dari acara Kopi Anda.

Tabel 7.

Distribusi Tanggapan Bernilai, Berkaitan dengan Publik Kopi Anda

\begin{tabular}{|l|c|c|}
\hline \multicolumn{1}{|c|}{ Publik yang dituju } & Jumlah Tanggapan & Prosentase (\%) \\
\hline Penyelengg ara Negara: & & \\
-Pem erintah/Eksekutif & 566 & 45,06 \\
-Legislatif/ DPR/D & 450 & 35,83 \\
-Yudikatif/Peradilan & 98 & 7,80 \\
\hline Lembaga Usaha/Bisnis & 24 & 1,91 \\
\hline LSM & - & - \\
\hline Individu/Masyarakat & 118 & 9,40 \\
\hline Jumlah & 1.256 & 100,00 \\
\hline
\end{tabular}

Sumber: Data Primer, 2005 
Salah satu unit yang berfungsi membantu melayani jalannya pemerintahan dan pembangunan dari pemerintah kota secara periodik/terjadwal setiap tanggal 17 Agustus, setelah apel, diteruskan dengan pertemuan para pejabat untuk mengolah data/informasi dari luar berupa kiriman SMS, surat kaleng dan resmi, berita dan surat pembaca dari koran, aspirasi langsung dari masyarakat, informasi hasil dari peninjauan, masalah yang dihadapi oleh masing-masing instansi, dan lain-lain informasi. Ketika peneliti menanyakan kepada pejabat teras yang biasa memimpin pertemuan itu, apakah bahan rapat termasuk informasi yang berasal dari RRI progama Pro 3 melalui dialog interaktif Kopi Anda, dengan durasi setengah jam dari pukul 06.30 sampai dengan pukul 07.00 pagi. Pejabat tersebut menjawab bahwa secara khusus tanggapan masyarakat dari Pro 3 (Kopi Anda), belum termasuk materi yang dibahas. Ketika ditanya mengapa demikian? Hal ini karena selain mereka tidak tahu, jika di RRI ada acara dialog yang dikemas dalam acara Kopi Anda dan menguntungkan bagi mereka, juga umumnya mereka jarang mendengarkan, bahkan nyaris tidak mendengarkan siaran radio. Menurut penuturan mereka, sebelum ke kantor, pada jam-jam tersebut mereka lebih banyak mengakses siaran berita dari stasiun televisi. Pola kebiasaan pejabat umumnya, setiap pagi sebelum pukul 06.00 menghidupkan televisi dengan acara keagamaan, diteruskan dengan acara televisi khususnya siaran berita sampai pukul 07.00, terus masuk kerja. Apa yang diungkapkan pejabat tersebut, nyaris sama dengan pejabat lain yang ditemui peneliti.

Ketika ditanyakan apakah di ruang kerjanya ada pesawat radio, atau di lingkungan kesekretariatan, dijawab tidak ada. Kami, lanjutnya, tidak terpikirkan bahwa di sela-sela bekerja dapat sambil mendengarkan siaran radio. Dalam wawancara tersebut, peneliti menjelaskan bahwa di RRI Pontianak, ada acara dialog Kopi Anda, yang banyak tanggapan dari masyarakat ditujukan kepada pemerintah (kota, provinsi), pejabat tersebut segera sadar dan seperti diingatkan bahwa ada sumber informasi yang penting, yaitu dari radio khususnya RRI Pontianak. Pejabat tersebut berjanji akan menempatkan pesawat radio minimal di ruang tunggu tamu dan ruang sekretariat, serta akan mendengarkan dengan intensif setiap hari acara interaktif Kopi Anda. Pejabat tersebut juga berjanji akan membawa tanggapan hasil dialog dan membahasnya dalam setiap rapat yang diadakan tanggal tujuh belas. Mereka mengungkapkan bahwa pihak RRI sampai hari ini belum pernah memberi masukan tentang acara tersebut, dan belum pernah meneruskan isi tanggapan masyarakat pada pemerintah kota.

Kepedulian legislatif terhadap tanggapan dalam interaktif Kopi Anda nyaris sama. Sebagaimana ketidakpedulian para eksekutif terhadap tanggapan yang masuk melalui acara Kopi Anda, tanggapan terhadap topik yang ditujukan kepada para legislator juga demikian. Berdasarkan hasil wawancara kepada tiga orang anggota DPRD Provinsi dan tiga orang anggota DPR Kota, tampak bahwa mereka nyaris tidak mendengarkan radio. Radio bukan sumber informasi yang populer lagi bagi anggota-anggota dewan. Radio dianggap tidak menarik lagi bagi mereka; radio juga dianggap tidak populer lagi di kalangan masyarakat. Para legislator lebih memanfaatkan surat kabar, televisi dan para petugas pencari informasi, serta lebih sering melakukan kunjungan kerja.

Ketika peneliti mananyakan apakah mereka tahu bahwa ada acara Kopi Anda yang sebenarnya amat perlu didengar dan diperhatikan bahkan perlu ditanggapai, mereka umumnya mengatakan tidak tahu. Oleh karena itu, ada beberapa hal menurut mereka mengapa tidak menagggapi apa yang disampaikan oleh masyarakat melalui RRI terutama acara Kopi Anda. Pertama, karena mereka tidak mendengarkan radio. Radio dianggap sebagai media yang tidak populer lagi. Padahal, dalam kenyataannya, RRI Pontianak selain menyuguhkan dua kali berita daerah pada jam 05.30 dan pada jam 17.00, juga merelai RRI pusat untuk menyuguhkan warta berita nasional (paling sedikit 9 kali, dan dua kali berita olah raga), ditambah secara insidental liputan upacara-upacara kenegaraan baik nasional maupun internasional.

Menurut mereka, seharusnya RRI proaktif 
untuk menyosialisasikan atau mempromosikan acaranya yang memang ditujukan kepada pihakpihak terkait. Karena kesibukan mereka masingmasing, ditambah dengan hampir tidak pernah mendengarkan siaran radio serta ketidaktahuan atas acara tersebut sehingga acara Kopi Anda yang seharusnya bermanfaat sebagai media komunikasi antara masyarakat dengan pemerintah dan wakilnya tidak dipedulikan mereka, tanggapan tersebut nyaris mubazir.

Saat peneliti menanyakan tentang tanggapan Kopi Anda lagi, apakah DPRD bersedia jika tanggapan tersebut dikumpulkan kemudian didiskusikan dengan eksekutif dan legislatif pada acara-acara tertentu, misalnya sebulan sekali pada acara Coffee Morning, "Saya sangat setuju, seharusnya memang demikian. RRI seharusnya memberitahu kami dan menyalurkan tanggapan yang masuk kepada pihak-pihak terkait," jawab anggota DPRD tersebut.

Selain DPRD Kota, peneliti juga melakukan wawancara dengan DPRD Provinsi. Umumnya, mereka juga sama, nyaris tidak mendengarkan siaran radio lagi. Mereka lebih memilih televisi dan surat kabar daripada sumber-sumber lain. Hal ini memang dapat dibuktikan, semua ruangan baik di ruang eksekutif di tingkat provinsi dan kota maupun ruangan legislatif di tingkat provinsi dan kota, ada sebuah pesawat televisi dan surat kabar. Tidak ada satu pun ruangan yang mempunyai radio.

Ketika ditanya, "Bapak kan setiap hari bepergian menggunakan mobil?’, Ya, jika sedang dalam perjalanan. "Apakah juga tidak on kan radionya?" Dengan lugas, mereka mengatakan tidak. Umumnya, mereka mendengarkan lagu-lagu dari kaset untuk teman di jalan. Apabila disimak, apa yang dikatakan bisa bermakna bahwa di era masyarakat informasi seharusnya kita selalu haus akan informasi dari berbagai sumber, tetapi kenyataannya tidak demikian.

Satu di antara anggota DPR, ketika diwawancarai, mengatakan pernah beberapa kali mendengarkan siaran Kopi Anda. Tetapi, karena yang menanggapi orangnya hampir itu-itu saja, mereka lalu tidak perhatian lagi, bahkan mereka tidak mendengarkan lagi. Pendapat ini sebenarnya tidak seluruhnya benar, karena data hasil penelitian, pendengar/penanggap bervariasi dan berganti. Hanya kebetulan mendengarkan acara Kopi Anda, pada saat itu pendengar dan penanggap itu muncul bersamaan dengan saat anggota dewan itu mendengarkan radio beberapa kali, maka mereka menyimpulkan demikian. Memang akhir-akhir ini beberapa figur pendengar dan sekaligus penanggap setia sering berpartisipasi dalam acara Kopi Anda. Menurut hasil penelitian publik Kopi Anda tidak didominasi orang-orang tertentu.

Jika diamati, kondisi ini sebenarnya sangat memprihatinkan, di mana rakyat yang telah memberikan kepercayaan kepada wakilnya untuk dapat membantu dan mendengarkan suara rakyat ternyata harapan itu menjadi tinggal harapan. Memang banyak kelebihan televisi daripada radio, selain suara televisi menyajikan gambar. Jadi, sesuai dengan prinsip komunikasi bahwa pesan yang disampaikan media sedapat-dapatnya ditangkap oleh panca indera, tidak dimilik oleh radio.

Hasil wawancara dengan seorang anggota dewan dari salah satu kabupaten yang agak jauh dari pusat pemerintahan propinsi (kabupaten Landak) menunjukkan bahwa hampir tidak mengenal radio, khususnya RRI, pada hal daerahnya masih terjangkau oleh siaran RRI. Dia beralasan bahwa tidak ada waktu untuk mendengarkan radio. Ketika ditanyakan, jika bepergian dengan alat transport apa, dia lebih banyak menggunakan kendaraan pribadi (roda empat). Pertanyaan diteruskan dengan, "Kan di dalam mobil ada tape recorder, yang sekaligus terdapat radio, apakah radionya tidak dihidupkan." Jawabannya, "Tidak." Dia lebih suka mendengarkan lagu-lagu yang berasal dari kaset. Ketika dijelaskan bahwa RRI mempunyai program berupa dialog interaktif dan dapat diakses hampir seluruh wilayah Kalbar dengan banyak masukan yang berguna bagi pemerintah, anggota dewan dan lain-lain pihak, anggota dewan ini mengusulkan RRI proaktif mensosialisasikan acara itu, serta memperkuat dan memperbaiki daya pemancar, agar siaran RRI dapat diterima dengan jelas. 


\section{Kesimpulan dan Rekomendasi}

\subsection{Kesimpulan}

RRI Pontianak sebagai Lembaga Penyiaran Publik, menyediakan ruang publikpada acara Pro 3 , setiap hari sebesar 195 menit atau 18,66\% dari jumlah jam siaran sebanyak 17 jam. Acara, Kopi Anda menyediakan ruang publik 30 menit (pukul 06.30-07.00), sebagai model dialog interaktif, mendapatkan sambutan positif dari masyarakat (pendengar/penanggap). Umumnya (58\%) topik ditanggapi antara 8 - 13 penaggap, dan rata-rata satu tanggapan/per orang memakan waktu sekitar 2 menit. Selama 6 bulan, ruang publik Kopi Anda menyediakan topik sebanyak 178 topik, jumlah tanggapan 1.744, dan jumlah tanggapan yang bernilai (ada keterkaitan dengan topik) sebanyak 1.256 .

Sebagian besar (80,89\%) tanggapan ditujukan pada pemerintah/eksekutif dan parlemen/legislatif. Pendengar/penanggap lebih banyak tertarik pada masalah politik, yaitu yang berkaitan dengan penyelenggara negara dalam melaksanakan fungsinya. Satu topik yang berkaitan dengan bidang politik ditanggaapi sampai 22 penagggap.

Pejabat eksekutif(sekretaris daerah, pimpinan kantor) dan legislatif (pimpinan dan anggota dewan), baik ditingkat provinsi maupun kota, tidak atau belum mengenal acara RRI Pro 3, khususnya Kopi Anda. Ada berbagai alasan mereka tidak mendengarkan siaran RRI. Sebagai media, radio dianggap tidak populer dibandingkan televisi. Umumnya, sumber informasi mereka adalah surat kabar, tv, dan orang tertentu sebagai pencari informasi. Mereka tidak tahu ada siaran Kopi Anda di RRI Pontianak yang seharusnya mereka dengarkan. Karena mereka tidak tahu, tanggapan yang disampaikan nyaris tidak pernah diperbincangkan, baik dalam rapat koordinasi maupun pertemuan-pertemuan lain. Rata-rata pejabat kurang memahami kelebihan radio dalam menyediakan informasi/berita yang cepat dan akurat serta diberitakan berulang-ulang.
Kelemahan acara Kopi Anda adalah tidak adanya tindak lanjut masukan/tanggapan oleh komunikan. Ada kesan mubazir karena pihak yang berkepentingan dengan tanggapan, nyaris tidak peduli/acuh terhadap pengorbanan masyarakat dalam waktu, biaya dan pemikiran untuk ikut berpartisipasi dalam pembangunan. RRI Pontianak dianggap kurang proaktif dalam mengiklankan dan menjual dirinya, juga kurang proaktif dalam memproses tanggapan sebagai hasil interaktifKopi Anda. Padahal pihak-pihak tersebut bersedia bekerja sama dengan RRI, dan mendukung sepenuhnya terhadap eksistensi RRI Pontianak sebagai Lembaga Penyiaran Publik.

\subsection{Rekomendasi}

Pemilihan topik perlu dipertajam, tidak hanya berdasar pada Pontianak Post pada rubrik "Metropolis". Perlu didiskusikan secara mendalam dengan tim manajemen, sehingga topik dapat dipertanggungjawabkan. Perlu adanya tambahan ruang publik, jika memungkinkan interaktif pada Kopi Anda waktunya ditambah, sehingga dapat lebih banyak lagi menampung aspirasi masyarakat. Narasumber interaktifDinamika Khatulistiwa sudah diprogramkan jauh hari, sehingga lebih siap. Tanggapan dengan Bebas Pulsa. Sebagai wujud dari tanggung jawab terhadap masyarakat, RRI harus dapat mengusahakan bebas pulsa bagi masyarakat yang akan memberikan tanggapan, dengan cara mengusulkan ke RRI Pusat, atau kerjasama dengan perusahaan Telkom.

Meningkatkan koordinasi dan kerjasama antara RRI Pontianak dengan instansi yang banyak mendapatkan feedback dari acara interaktif. Pihakpihak tersebut hendaknya proaktif mengakses informasi. Perlu adanya Gerakan Memasyarakatkan Radio, mengingat radio telah ditinggalkan oleh pemirsanya, padahal berita-berita radio cukup akurat dan baru, disiarkan berulang-ulang, menjangkau wilayah yang luas. Gerakan ini harus diangkat pada tingkat nasional. 


\section{Daftar Pustaka}

Baran, S. J. \& Davis, D. K. 1979. Mass Communication Theory, Fondations, Ferment, and Future. Singapore: Wadsworth Thomson Learning.

Bungin, B. 2001. Metodologi Penelitian Sosial Format-format Kualitatif dan Kuantitatif, Surabaya: Airlangga University Press.

Effendy, O. U. 1984. Ilmu Komunikasi Teori dan Praktek, Bandung: Penerbit Alumni.

Grunig, J.E. \& Hunt, T. 1984. Managing Public Relations, Fort Worth: Holt Reinhart \& Winston.

Krippendorff, K. 1991. Analisis Isi Pengantar Teori dan Metodologi, Jakarta: Rajawali Press.

Komisi Penyiaran Indonesia. 2004. Pedoman Perilaku Penyiaran dan Standar Program Siaran: Jakarta.

Lasswel, H. 1948. The Structure and Function of Communication in Society, The Communication of Ideas, L, Bryson, Editor, New York: Institute for Religious and Social Studies.

Mowlana, H. 1986. Global Information and World Communication, New Frontiers in International Relations, New York: Longman.
Mulyana, D. 2002. Metodologi Penelitian Kualitatif, Paradigma Baru Ilmu Komunikasi dan Ilmu Sosial Lainnya, Bandung: PT Remaja Rosdakarya.

Parwadi, R. 2004. Televisi Daerah Diantara Himpitan Kapitalisme Televisi, Pontianak: Badan Penerbit Universitas Tanjungpura.

Rakhmat, J. 2001. Psikologi Komunikasi, Bandung: Penerbit PT Remaja Rosda Karya.

Radio Republik Indonesia Cabang Pontianak. 2003. RRI Pontianak Dari Masa Ke Masa, Pontianak.

Quail, Mc., Windal, S. 1993. Communication Models, For The Study of Mass Communication, London and New York: Logman

Saleh, M. 2005. Makalah: "Upaya Menjadikan RRI Sebagai Radio Publik Yang Dipercaya, Menarik, Melibatkan Publik dan Laku Dijual", Pontianak: tidak diterbitkan.

Undang Undang Republik Indonesia No. 32 No. 32 Tahun 2002 Tentang Penyiaran dam PP. No. 11 Tahun 2005 Tentang Lembaga Penyiaran Publik, Jakarta. 
